\title{
Beyond 1979 and 2011: When Comparisons Distract Arang Keshavarzian
}

\author{
Department of Middle Eastern and Islamic Studies, New York University, \\ New York, N.Y.; e-mail: arang.keshavarzian@ nyu.edu \\ doi:10.1017/S0020743811001334
}

In the midst of several research trips to Iran in the 1990s, I spent one year living and conducting exploratory research in Cairo. In Tehran, revolution seemed unfinished if not perpetual, yet in Egypt it was unimaginable. In spite of the entrenched support for the Leader and the political status quo, at this time Iran's reformist movement was robust. The policies of the Islamic Republic and consequences of the eight-year war with Iraq unleashed new social conditions that combined with established forces to push for women's rights, freedom of speech, independent civil associations, and exposing contradictions in the postrevolutionary order.

The mood and discussions about politics in Egypt and much of the Arab world were quite different from those in Iran at the turn of the millennium. Academics, analysts, and ordinary Egyptians downplayed the political efficacy of Egyptian society and emphasized the will and capacity of the Mubarak regime to withstand opposition, nurture political apathy, and cultivate key allies. On more than one occasion, I heard that "Egyptians are not a protesting nation." The implicit comparison was with Iranians; Iran's postrevolutionary polity, not Egypt's unresponsive and ineffective regime, readily conjured up images of contestation and even regime transformation. Thus, when the political movement after the 2009 presidential elections emerged, pundits readily interpreted it as a harbinger of profound political change, if not a whole new revolution. Ironically, as the Green Movement has been suppressed and demobilized, Egypt and much of the rest of the Arab world have taken center stage with their unthinkable uprisings.

This sort of misplaced "common wisdom" is reminiscent (but in reverse) of the late 1970s, when Iran's Pahlavi regime was the "island of stability" protected by support from the United States, financed by oil revenues, and believed to be aligned with the "modernizing" middle class. At that time, it was Egypt that was in the midst of social turmoil and political volatility; the passing away of al-Nasir and with him the Arab socialist social contract left the political elite vulnerable to economic grievances (e.g., the 1977 riots) and ideological critique. Yet, while Sadat was assassinated shortly after the deposed shah was buried in Cairo, "the killing of the Pharaoh" did not usher in the mass revolution that the Egyptian Islamic Jihad so desired. Hence, we should not be surprised that revolutionary outcomes are difficult to foresee, let alone predict. Indeed, the social scientific literature on revolutions in the past three decades has increasingly stressed the unpredictability of revolutions, by moving away from grand theories and toward more modest approaches. They have done this by focusing on mechanisms and processes of social mobilization and paying greater attention to subjective experiences and perceptions of participants.

Nonetheless, from the outset of what would become known in the United States as "the Arab Spring," pundits began trotting out the specter of Tehran 1979. Ideologically 
driven and with the unabashed desire to preserve geopolitical interests, many of these commentaries presented stylized accounts of the Iranian Revolution to warn against enthusiasm for the protestors in Tunisia, Egypt, Yemen, and Bahrain. They asserted that an Egypt without Mubarak would be dominated by the Muslim Brothers, who in turn were cast as Khomeini's kin. Putting aside the highly problematic equation of today's Muslim Brothers with yesterday's Khomeinists, this sort of argument implied that it was inevitable that Khomeini's allies would be able to dominate the broad, multiclass, and ideologically diverse coalition that crystallized during the revolution. The lesson from studying the events of 1979-81 is that if revolutionary moments and outcomes are unpredictable, so too are their dynamics. The fluid and chaotic aftermath of the shah's departure fashioned an avenue to state power for Khomeini, but it is unclear and unlikely that in Egypt the same sort of mix of political skill, organizational fragmentation, international forces, and historical contingencies will work in favor of the establishment of an Islamist regime.

Rather than imposing a stylized model of the Iranian Revolution upon Egypt, let alone the entire "Arab Spring" at this early stage, one lesson that I would like academics to draw from 1979 is to take the historical process of social mobilization and regime breakdown seriously. To fully understand the overthrow of Bin 'Ali, Mubarak, and alQadhafi as well as the persisting structures and the new and diverse forces that were unleashed in their stead, we need detailed histories documenting the actors, alliances, and junctures that open and foreclose certain historical trajectories. We have no shortage of works on the Iranian Revolution and in fact have a rich array of analyses. Some studies take a comparative perspective to test existing theories, some present macrostructural readings of the conditions that facilitated the breakdown of the regime, and others focus on specific sectors of society (e.g., labor, women, and the clergy). We also have a host of memoirs, official records, chronologies published by the current regime, and oral history projects. However, even three decades since these landmark events, we do not have detailed and comprehensive histories, especially ones that go beyond Tehran to incorporate provincial cities (e.g., Abadan or Tabriz) and rural peoples. This lacuna prevents us from fully examining the revolution to account for the myriad experiences and logics that were at work. Fortunately, scholars in and of the Arab world are currently well positioned to create archives, document events, and write prospective (rather than retrospective) narratives. ${ }^{1}$ These will not only be invaluable for future generations of researchers but also promise to offer lessons and mappings for contemporary Egyptian activists as well as their counterparts in Iran.

In short, if echoes do resonate between 1979 and 2011, they are likely indirect, subtle, and multifocal. Their reverberations are more attuned to the concrete local and international conditions and the constellations of social forces implicated in these monumental ongoing struggles. The dynamics of contestation in Iran, Egypt, Tunisia, Bahrain, Libya, and beyond should foster humility and patience among academics and policymakers alike. Comparisons with 1979 or even 2009 may very well limit the questions we ask about the revolutionary moments today and distract us from studying the plurality of demands and participants continuing to shape these polities. Before imposing blueprints from the Iranian case upon the 2011 Arab protest movements, we must have a sound grasp of these revolutionary moments and their highly politically charged processes with unclear beginnings and indeterminate ends. 


\section{NOTE}

${ }^{1}$ In Egypt, a Committee of Documenting the Revolution was launched by the Egyptian National Library and Archives. See http://www.albawaba.com/auc-history-chair-leads-egyptian-national-library-and-archivescommittee-documenting-revolution (accessed 27 September 2011). 